\title{
間歇性外斜視に対する融像訓練の臨床経験
}

\author{
野 邊 由美子・中 村 桂 子・滇 村 美恵子

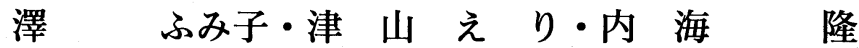 \\ (大阪医科大学 眼科学教室)
}

\section{Effectiveness of Fusion Training in Patients with Intermittent Exotropia}

\author{
Yumiko Nobe, Keiko Nakamura, Mieko Hamamura \\ Fumiko Sawa, Eri Tsuyama, Takashi Utsumi \\ Department of Opthalmology Osaka Medical College
}

\begin{abstract}
間歇性外斜視 23例に対し融像訓練を行った。対象は 3 群からなる．A 群；輻湊不全を伴わず遠見 時外斜視を呈する 5 例, $\mathrm{B}$ 群; 輻湊不全を伴い遠見時外斜視を呈する 6 例, $\mathrm{C}$ 群; 輻湊不全のみを呈 する 12 例である. A 群および B 群の遠見時外斜視を呈する 11 例に対し赤フィルターによる抑制除去 訓練を行った（ 4 〜 週間）ところ, 全例で遠見時外斜位の状態を保つことが可能となった. 遠見時 抑制除去後の B 群およびC 群の輻湊不全を示す 18例に対し生理的複視認知の有無を検査したところ, 不安定 8 例， 欠如 10 例であったので，鉛筆 2 本による生理的複視認知訓練を行い ( $2 \sim 4$ 週間), 生 理的複視の認知を安定させた後，フレーミングカード，3点カード，ステレオカードによる融像訓練

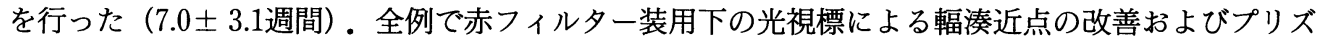
ム融像幅が向上した．融像訓練は融像機能向上にきわめて有用であることがわかった。
\end{abstract}

On twenty-three patients with intermittent exotropia, fusion training was successfully performed. Subjects were devided into three groups; Group A; five patients who had suppression and exotropia at distant with out convergence insufficiency, Group B; six patients who had suppression and exotropia at distant associated with convergence insuffciency and Group C; twelve patients who had exophoria without suppression at near as well as at distant associated with convergence insufficiency. In group A and group B patients, anti-suppression therapy using a red filter, a flashing method was adopted by us orthoptists and themselves for 2 to 4 weeks, and they obtained the ability to maintain the fusion and exophoria at distant. Since group B patients whose suppression had been abolished by a flashing method and group $\mathrm{C}$ patients showed some impairments or loss of physiological diplopia at near, we trained then by a two-pencil method. Their recognition of physiological diplopia became manifest and was stabilized in 2 to 4 weeks. Thereafter, a fusion training was performed using a framing card, a 3-dot card and stereo cards. Near points of convergence in group B and group $\mathrm{C}$ patients measured by a penlight through a red filter were extraordinarily improved in $7.0 \pm 3.1$ (mean \pm standard deviation) weeks. Fusion amplitude was also augmented. We think that the anti-suppression therapy and the physiological diplopia training are very useful to maintain and stabilize the fusion and that the fusion training is also a clinically effective technique to increase the fusion ability in patients with intermittent exotrpia.

$\begin{array}{ll}\text { 連絡先 } & \text { ( } 5569) \text { 高梘市大学町 } 2-7 \\ & \text { 大阪医科大学病院眼科 } \\ & \text { TEL (0726) 83-1221 内2334 }\end{array}$

Key words: intermittent exotropia, convergence insufficiency, anti-suppression therapy, physiological diplopia, fusion training.

\section{I. 緒 言}

眼位ずれが目立たず両眼視機能（近見立体視） がよい間歇性外斜視に対して，これまでは視能 訓練などの積極的な治療は行わず，両眼視機能 
の退行や眼位ずれの増大に重点をおいて注意深 く経過観察をしてきた。しかし，場合によって は抑制が引き金となり，外斜位の状態を保てず 外斜視に移行し, 融像機能が低下していく例が あり，この時期に積極的に融像訓練を行うと融 像機能の低下を防ぐことができ，斜位の状態を 保つことが可能であるという金谷らによる積極 的な取り組みが報告されている(1)2)，また，VDT 作業の増加に伴い，近見霧視，複視といった眼 精疲労を訴える患者の中には，輻湊不全が原因 で発症している場合もあり，こうした症例に対 しても輻湊を中心とした融像訓練が欧米では古 くから行われ ${ }^{3 / 4) 5)}$, 本邦でも井上 ${ }^{6)}$, 金谷 ${ }^{1)} に$ より紹介されて報告されているにもかかわらず， まだ融像訓練は広くは普及していないように思 われる，そこで今回われわれは，間歇性外斜視 および輻湊不全を呈する症例に対して，金谷ら の方法 ${ }^{1)} に$ 基づき融像訓練を行ったところ良好な 結果を得たので報告する。

\section{II. 対 象}

対象は以下の 3 群の計 23例である.A 群：輻 湊不全を伴わず，遠見時外斜視を呈し，抑制が 認められる間歇性外斜視群 5 例（年齢；9 歳〜 18歳）。

B 群：輻湊不全を伴い, 遠見時外斜視を呈し, 抑制が認められる間歇性外斜視群 6 例（年齢； 8 歳〜35歳).

C 群：輻湊不全を伴い，遠見時抑制の認められ ない間歇性外斜視群 12例（年齢；8 歳 33歳）。

いずれの症例も（1.0）以上の良好な矯正視力 を有し, grade III レベルの両眼視機能の基礎があ る症例である。

各症例毎の斜視タイプ, 両眼視機能は表 1 に
示す．訓練の理解，協力性を考慮し対象年齢は 8 歳以上とした。訓練対象となる症例の眼位と しては，訓練によって眼位ずれそのものは軽減 できない吕めめ, 眼位ずれ $20 \triangle$ 以下の症例とし た、調節視標および赤フィルター片眼装用下の 光視標を用いた輻湊近点を測定し，輻湊近点が 著しく延長あるいは輻湊不能である場合に輻湊 不全と診断した。また，調節視標で輻湊近点が 良好であっても, 赤フィルター片眼装用下光視 標の輻湊近点が著しく延長あるいは輻湊不能で ある症例があり, 今回は赤フィルター片眼装用 下の光視標の值をもって輻湊不全と診断した ${ }^{1)}$.

\section{III. 方 法}

金谷らの方法 $(\text { 表 } 2)^{1)}$ に準拠して融像訓練を 行った. A 群および B 群に対しては，まず外来 および家庭にて赤フィルターによる抑制除去訓 練から開始した。次に, 抑制除去訓練により遠 視時外斜視の状態から外斜位の状態を保つこと ができ，両眼視機能が完全になった B 群および $\mathrm{C}$ 群に対し，輻湊を中心とした融像訓練，すな わち鉛筆 2 本による生理的複視訓練, フレーミ ングカードによる融像訓練， 3 点カードによる 融像訓練, ステレオカードによる融像訓練を家 庭にて行わせたＡ 群は輻湊不全を呈していな かったため抑制除去訓練のみを行った．訓練の 効果の判定は，2 週間毎に視能訓練士が行った。 なお，訓練効果の判定には Wilcoxon の符号順 位検定を用いた。

\section{IV. 結果}

\section{1. 赤フィルターを用いた抑制除去訓練}

$\mathrm{A}$ 群 5 例, B 群 6 例の全例で, 遠見時におい て外斜視の状態から外斜位の状態を保つことが

表 2 融像訓練

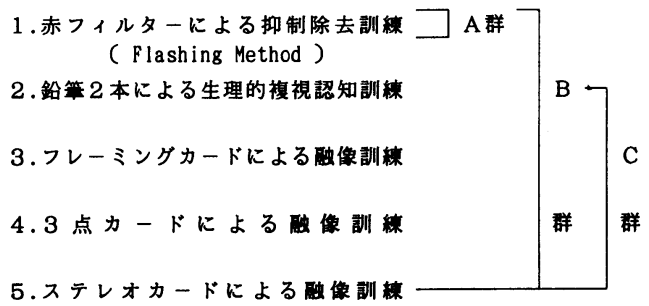


表 3 生理的複視の認知訓練の結果

\begin{tabular}{|c|c|c|}
\hline \multirow{2}{*}{ 群 } & \multicolumn{2}{|c|}{ 生理的複視の認知 } \\
\hline & 訓 練 前 & $\longrightarrow$ 訓練 後 \\
\hline B & $(-) \sim( \pm)$ & $\rightarrow(+)$ \\
\hline $\mathrm{C}$ & $(-) \sim( \pm)$ & $\rightarrow \quad(+)$ \\
\hline
\end{tabular}

$( \pm)$; 認知不安定

表 4 訓練による遠見時斜視のタイプの変化

\begin{tabular}{ccc}
\hline \multirow{2}{*}{ 群 } & \multicolumn{2}{c}{ 遠見時の斜視のタイプ } \\
\cline { 2 - 3 } & 訓綀前 & $\rightarrow$ 訓練 後 \\
\hline $\mathrm{A}$ & $\mathrm{X} \mathrm{T}$ & $\rightarrow \mathrm{X} \sim \mathrm{X}(\mathrm{T})$ \\
$\mathrm{B}$ & $\mathrm{X} \mathrm{T}$ & $\rightarrow \mathrm{X} \sim \mathrm{X}(\mathrm{T})$ \\
\hline
\end{tabular}

できるようになった（表 3 ）。訓練の量としては, $\mathrm{A}$ 群 5 例中 3 例は外来での $1 \sim 1.5$ 時間の訓練の みにて著効を示した. 残り 2 例および B 群の全 例は, 赤フィルター装用にて複視が認知できる ようになった後, 外来のみの訓練では不完全な ため, 家庭でも抑制除去訓練を行ってもらった。 訓練の期間としては, 全体としてほほ $4 \sim 6$ 週 間（3.5土1.4週間）を要した。全例において遠 見時の抑制は除去され, 複視の自覚を経て斜位 を保つことができるようになった．特に，遠見 時における外斜視時の眼位ずれが外見的に目立 つ症例（A群 3 例，B群に 4 例の計 7 例) では; 斜位に持ち込めるようになって外見が著しくよ くなり, 抑制除去訓練は非常に効果的であった。 しかし, 眼位ずれの量そのものは特に変化しな かった。

\section{2. 輻湊を中心とした融像訓練}

遠見時に外斜位を保つことができるようになっ た後の B 群 6 例全例および C 群 12 例全例の, 輻 湊不全を認める計 18 例に対して生理的複視の認 知の有無を検査したところ, B 群 6 例中全例, C 群 12 例中 3 例が抑制を, 残り 9 例が認知不安定 という生理的複視の抑制を認めた.そこで,ま ず鉛筆 2 本による生理的複視認知訓練から開始
表 5 訓練による輻湊近点の変化

\begin{tabular}{|c|c|c|c|c|c|}
\hline \multirow{2}{*}{ 群 } & \multirow{2}{*}{\multicolumn{2}{|c|}{ 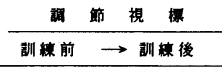 }} & \multicolumn{3}{|c|}{ 赤フィルター装用下光視楞 } \\
\hline & & & 訓練 & 前 & $\rightarrow$ 訓 紻 後 \\
\hline B & $7.3 \pm 2.3$ & $\rightarrow 1.3 \pm 1.0$ & $\begin{array}{c}\text { 湅湊不能 } \\
10.0\end{array}$ & $\begin{array}{l}(5 \text { 例 }) \\
(1 \text { 例 })\end{array}$ & $\rightarrow 1.7 \pm 1.5$ \\
\hline $\mathrm{C}$ & $7.2 \pm 5.6$ & $\rightarrow 3.3 \pm 2.4$ & $\begin{array}{r}\text { 㬏溇不能 } \\
18.1 \pm 5.2\end{array}$ & $\begin{array}{l}(5 \text { 例 }) \\
(7 \text { 例 })\end{array}$ & $\rightarrow 3.9 \pm 2.3$ \\
\hline
\end{tabular}

調節視標 赤フィルター装用下光視標

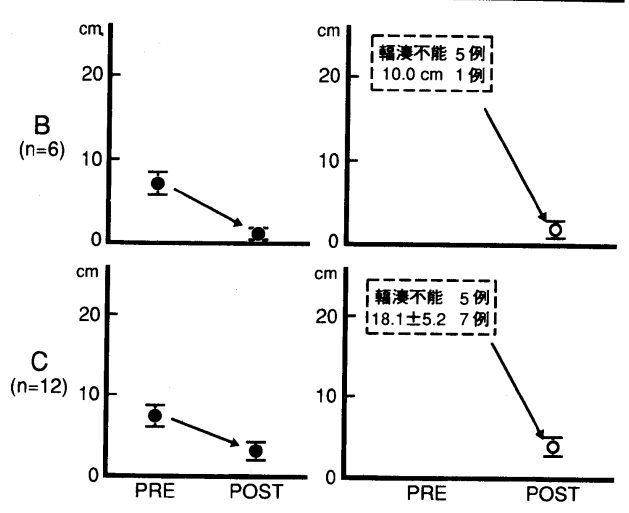

図 1 輻湊近点の訓練による変化：表 5 を図にしたも の. 訓練により B 群および C 群の輻凑近点は, 調節視標による場合も著明に値が小さくなって いる $(p<0.05)$. 縦軸は輻湊近点 $(\mathrm{cm})$, 図中 の丸と bar は平均値と標準偏差, PRE; 訓練前, POST; 訓練後.

し, 複視の認知が安定した後 $(2 \sim 4$ 週間, 表 $4)$, フレーミングカードによる融像訓練, 3 点 カードによる融像訓練, ステレオカードによる 融像訓練へと進み, 生理的複視の安定をはかっ た. 全例で赤フィルター片眼装用下の光視標で の輻湊近点が改善し $(p<0.05)$ (表 5 , 図 1$)$, プリズム融像幅の拡大を得た $(p<0.05)$ (表 6 ,

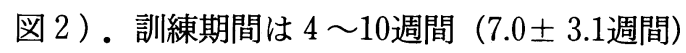
であった。

特にVDT 作業による近見時の霧視, 眼精疲 労を訴えて来院したC 群中の一例 (33歳, 男性) では, 調節機能は異常はなかったのにもかかわら ず, 眼位ならびに輻湊近点を検査したところ, 調 節視標での輻湊近点の延長および赤フィルター 装用下の光視標での輻湊が不能であることが検 出され, 輻湊不全の存在が認められた。そこで 上述の融像訓練（2本の鉛筆による生理的複視 認知訓練, フレーミングカードおよびステレオ カードによる融像訓練）を家庭にて 8 週間行わ 
表 6 訓練によるプリズム融像幅の変化

\begin{tabular}{|c|c|c|c|c|c|c|}
\hline \multirow{2}{*}{ 群 } & \multirow{2}{*}{$\begin{array}{c}\text { 固視の } \\
\text { 位置 }\end{array}$} & \multicolumn{2}{|c|}{ Blur point } & \multicolumn{3}{|c|}{ Break point } \\
\hline & & 訓練前 & $\rightarrow$ 郡練後 & 研赫前 & $\rightarrow$ & 䚴站後 \\
\hline \multirow{2}{*}{ A } & 近見 & $37.3 \pm 6.2$ & $\rightarrow 49.6 \pm 11.5$ & $42.8 \pm 14.3$ & $\rightarrow 54$ & $4.0 \pm 17.3$ \\
\hline & 薏見 & $3.6 \pm 8.0$ & $\rightarrow 28.6 \pm 3.0$ & $3.6 \pm 8.0$ & $\rightarrow 38$ & 8. $6 \pm 12.1$ \\
\hline \multirow{2}{*}{ B } & 近見 & $5.2 \pm 7.2$ & $\rightarrow 51.8 \pm 17.2$ & $7.7 \pm 8.8$ & $\rightarrow 65$ & $5.8 \pm 25.8$ \\
\hline & 遠見 & $4.3 \pm 10.6$ & $\rightarrow 34.3 \pm 11.6$ & 4. $3 \pm 10.6$ & $\rightarrow 49$ & $9.7 \pm 30.3$ \\
\hline \multirow{2}{*}{$\mathrm{C}$} & 近見 & $21.4 \pm 14.2$ & $\rightarrow 40.1 \pm 10.7$ & $22.6 \pm 14.9$ & $\rightarrow 51$ & $1.1 \pm 18.6$ \\
\hline & 德見 & $17.6 \pm 7.4$ & $\longrightarrow 30.3 \pm 13.8$ & $18.9 \pm 7.9$ & $\rightarrow 38$ & $3.3 \pm 18.9$ \\
\hline
\end{tabular}

せたところ，赤フィルター装用下の光視標での 輻湊近点の改善（輻湊不能 $\rightarrow 7 \mathrm{~cm}$ ）とともに融 像機能が向上し, 近業作業時の疲労が著しく軽 減した。

\section{V. 考按}

\section{1. 抑制除去訓練について}

間歇性外斜視から恒常性外斜視への移行は抑 制を引き金として起こってくるため，まず抑制 を充分に除去し複視を認知させることによって， その後の斜位の状態を保つことが可能となる. 本研究においても, 抑制が認められる例（A 群 および B 群) に対して抑制除去訓練を行ったと ころ, 全例において赤フィルター装用下での複 視の認知が可能となり，次に赤フィルターを装 用せずとも外斜視時には複視を認知 (自覚) し 得るようになって斜位に持ち込むことが可能と なった。すなわち，両眼視機能の抑制に対して は本研究において行った抑制除去訓練がきわめ て有用であることがわかった。

\section{2. 輻湊不全に対する融像訓練について}

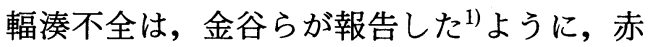
フィルター装用下に光視標を固視させた時の輻 湊近点を測定することによって，的確な診断が 可能であることがわかつた。 また，今回の結果か らも, 特に輻湊不全を呈する症例（B群および C 群) では，生理的複視の認知が欠如している症 例がほとんどであり, 耳側網膜のみならず鼻側 網膜までも抑制が認められた。そこで, 生理的複 視の認知を中心とした融像訓練を行ったところ, 全例で輻湊近点の正常化に伴う輻湊不全症状の 改善およびプリズム融像幅で示される融像機能 の向上を得た。この結果は, 生理的複視の認知 の有無, すなわち耳側ならびに鼻側網膜の抑制

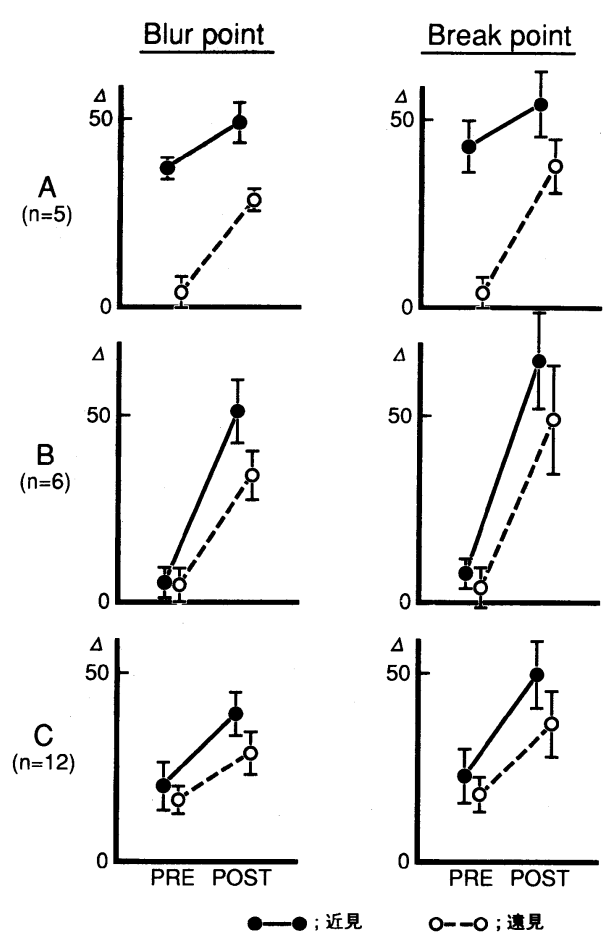

図 2 プリズム融像幅の訓練による変化：表 6 を図に したもの. Blur point, Break point ともに, 遠 見, 近見を問わず全ての群において著明に值が 増大している $(p<0.05)$. 縦軸はプリズム融 像幅 $(\triangle)$, 図中の丸と bar, PRE, POST の意 味は図 1 と同じ.

の有無が融像機能を大きく左右し, 鍵となって

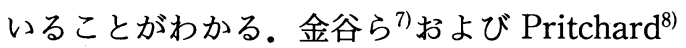
は, 間歇性外斜視においては斜位の状態を保つ ことができて近見立体視が良好であってもよし とせず，その感覚面に重きをおいて生理的複視 の認知の有無を検査することが重要であると述 べ, 何らかの感覚異常が影響して斜位から恒常 性外斜視へ移行するのではないかと考察してい る。また, Kertesz ${ }^{9)}$ は, 輻湊不全では大型弱視 鏡などを用いて広い範囲で網膜を刺激すること によって融像機能が向上し, 輻湊不全の症状が 改善されると報告している、いずれの報告から も網膜の抑制が鍵になるものと考えられる。す なわち, 立体視に代表される両眼視機能の有無 のみで間歇性外斜視の感覚面の評価をするので はなく, 生理的複視の認知の有無を含めたより 広い感覚面からの検討の必要性が痛感された。 


\section{VI. 結 論}

間歇性外斜視 23例を対象に融像訓練を行い, 検討を加えた結果，赤フィルター装用による抑 制除去訓練は遠見時外斜視の状態から外斜位の 状態に持ち込むために非常に効果的であった.ま た，間歇性外斜視症例では，生理的複視の認知 の有無を検査することが重要であり，特に，輻 湊不全を有する症例に対しては生理的複視の認 知を中心とした訓練によって, その融像機能（輻 湊近点, プリズム融像幅）が著明に改善するこ とが明らがとなった，以上のことから，赤フィ ルター抑制除去訓練, 生理的複視の認知ならび に輻湊を主とした融像訓練は, 間歇性外斜視に おいてその病態を改善するために臨床的にきわ めて有用なものであると考える.

稿を終えるにあたり東郁郎教授の御校閲に心 より深謝致します。

\section{文献}

1）金谷まり子，他：駿河台日大病院眼科における 融像訓練一輻湊を中心として. その 1 . 検査と 訓練方法，臨眼，81: 1271-1276, 1987.

2）金谷まり子，他：駿河台日大病院眼科における 融像訓練一輻湊を中心として。 その 2 . 結果, 眼臨, $82: 343-350,1988$.

3) Luke, N. E. : Antisuppression techniques in exodeviations, Am. Orthopt. J., 15: 42-47, 1965.

4) Rapport, A. T. : Orthoptic techniques: Physiological techniques, Am. Orthopt. J., 20: 127-135. 1970.

5) Pappas, J. E. : Modern orthoptic treatment: Expectations and limits, Am. Orthopt. J., 37: 45-49. 1987.

6) 井上治彦：斜位の治療法，眼科，11：981-991, 1969 .
7) 金谷まり子, 他：間歇性外斜視における生理的 複視の抑制, 眼臨, 85: 1940-1946, 1991.

8) Pritchard, G and Flynn, J. T. : Suppression of physiologic diplopia in inter mittent exotropia, Am. Orthopt. J., 31: 72-79, 1981.

9) Kertesz, A. E. : The effectiveness of wideangle fusional stimulation in the treatment of convergence insufficiency, Invest. Opthalmol. Vis. Sci., 22: 690-693, 1982.

質問 （兵庫医大）河内 裕美 当院でも，同様な訓練を施行しておりますが，訓 練中に近視化した症例を経験致しましたが, その点 について如何でしょうか.

答弁

ご指摘の通り，私どもも訓練対象とした眼位ずれ が $25 \triangle$ 以上の症例では, 融像性輻湊のみでは斜位に 持ち込めず, 調節性輻湊の関与により調節と輻湊の バランスが崩れ近視化した症例を経験しております。 このことより, 訓練対象の眼位偏位量の選択に際し ては, 充分に注意が必要と考え, 近視化傾向の出現 をみた時は，訓練を中止する必要があると考えます。

質問

(岐阜大学) 浅野紀美江

遠見でのプリズム融像幅の日常的訓練の実際をお 教え下さい.

答弁

プリズム融像幅の測定は, 明室にてバープリズム を片眼あるいは両眼に負荷していき，その際の調節 視標のボヤケた点を blur point, 2 つに見えた点を break point として測定しています。

実際, 訓練前後のプリズム融像幅の増加には, プ リズムを徐々に負荷していく方法は用いず講演でも 述べましたように，抑制を除去していく事で，プリ ズム融像幅の増大を得ております。

質問 (熊本大学) 帆足悠美子

融像訓練前の両眼視の状態で gradeIIIがあったと いう high grate の立体視が（+）であったという事 でしょうか.

答弁

Grade III としておりますのは，大型弱視鏡による 両眼視機能が立体視まで完全なものです. 